\title{
Synthesis, biological evaluation and molecular modeling studies of the PPARß/ס antagonist CC618
}

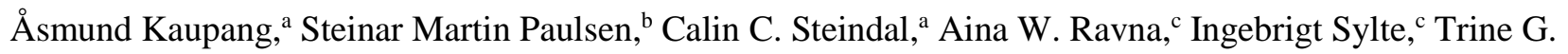
Halvorsen, ${ }^{a}$ G. Hege Thoresen ${ }^{\mathrm{d}}$ and Trond Vidar Hansen ${ }^{\mathrm{a}^{*}}$

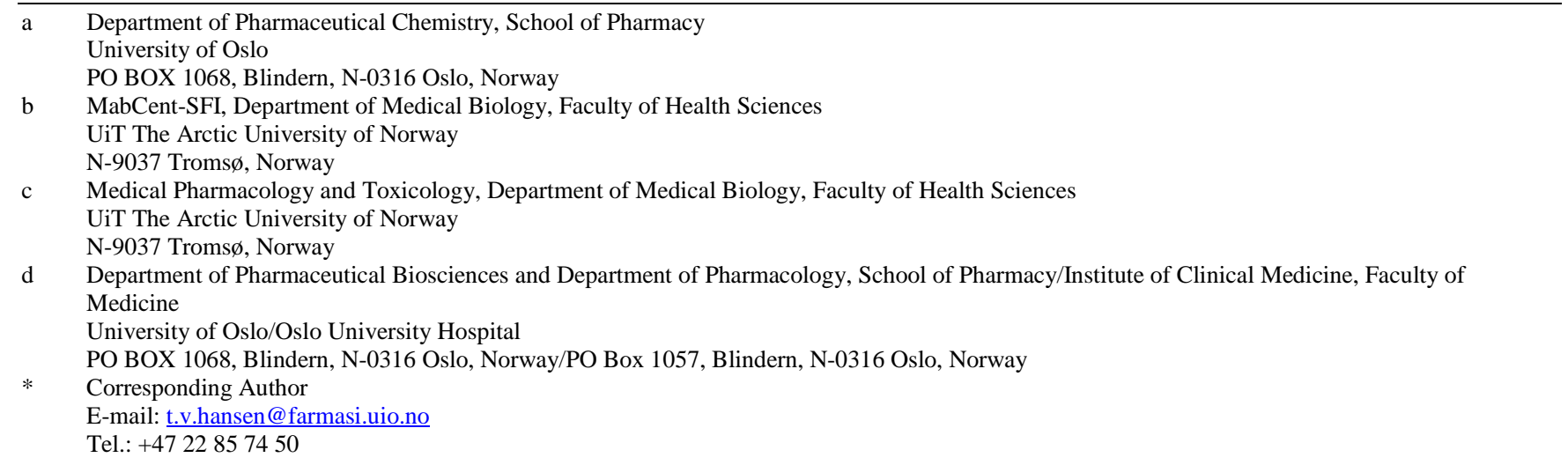

\begin{abstract}
Herein, we describe the synthesis, biological evaluation and molecular docking of the selective PPAR $\beta / \delta$ antagonist (4-methyl-2-(4-(trifluoromethyl)phenyl)- $N$-(2-(5-(trifluoromethyl)-pyridin-2-ylsulfonyl)ethyl)thiazole-5carboxamide)), CC618. Results from in vitro luciferase reporter gene assays against the three known human PPAR subtypes revealed that CC618 selectively antagonizes agonist-induced PPAR $\beta / \delta$ activity with an $\mathrm{IC}_{50}=10.0 \mu \mathrm{M}$. As observed by LCMS/MS analysis of tryptic digests, the treatment of PPAR $\beta / \delta$ with CC618 leads to a covalent modification of Cys249, located centrally in the PPAR $\beta / \delta$ ligand binding pocket, corresponding to the conversion of its thiol moiety to a 5trifluoromethyl-2-pyridylthioether. Finally, molecular docking is employed to shed light on the mode of action of the antagonist and its structural consequences for the PPAR $\beta / \delta$ ligand binding pocket.
\end{abstract}

Keywords: PPAR $\beta / \delta$, antagonist, covalent, Cys249, LC-MS/MS

Abbreviations: PPAR; peroxisome proliferator-activated receptor, LC-MS; liquid chromatography - mass spectrometry, LBP; ligandbinding pocket, LBD; ligand-binding domain, ABC; ammonium bicarbonate.

\section{Introduction}

The peroxisome proliferator-activated receptors (PPAR $\alpha$, PPAR $\beta / \delta$ and PPAR $\gamma$, NR1C1-3) belong to the nuclear hormone receptor superfamily and function as ligandactivated transcription factors [1]. The PPAR receptor subtypes display tissue-specific distribution patterns, with $\mathrm{PPAR} \beta / \delta$ being the most abundant in skeletal muscle. The receptors play key roles in the induction of genes involved in carbohydrate and lipid metabolism and storage [2]. PPARs also impart on the processes of wound healing, cell differentiation and cancer [3-5]. Fatty acids and some of their metabolites, as well as synthetic ligands, can modulate transcriptional activity through the PPARs, rendering support for the notion that these receptors function as sensors for both endogenously and exogenously derived ligands [6]. The synthesis and development of selective ligands have proved instrumental in understanding the biological roles of the PPARs [7]. In the early days of PPAR research, the use of selective agonists against the three known PPAR subtypes was particularly important [8]. In the context of PPAR $\beta / \delta$, the carboxylic acid GW501516 (1, Figure 1) $[9,10]$ has seen widespread use as a pharmacological tool. Later, potent and selective PPAR $\alpha$ and PPAR $\gamma$ antagonists, such as GW6471 (2) [11] and GW9662 (3) [12], were introduced (Figure 1). Recent evidence for the involvement of PPAR $\beta / \delta$ in additional cellular functions [13-16] justifies the need for further development of antagonistic modulators of the $\beta / \delta$-subtype [17].

In 2008, Shearer et al. identified GSK0660 (4) via a highthroughput screen against PPARs of a GlaxoSmithKline inhouse compound collection. GSK0660 (4) displayed an IC $_{50}$ value of $155 \mathrm{nM}$ against $\mathrm{PPAR} \beta / \delta$, and nearly ten-fold selectivity over the other PPAR subtypes. The antagonistic properties of GSK0660 (4) were established through the observation of downregulation of GW501516-induced transcription of bona fide PPAR $\beta / \delta$ target genes. However, due to rapid clearance in rodents, GSK06660 (4) was not suited for further in vivo studies [18]. Later, Müller and coworkers used GSK0660 (4) as a lead-compound for structure-activity studies leading to e.g. the analogue ST247 (5), with improved bioavailability and binding affinity $[19,20]$. The same research group recently developed the acrylonitrile compound DG172 (6) which exhibited potent $\mathrm{PPAR} \beta / \delta$ antagonism and oral bioavailability [21]. As carboxylic acids are canonical agonists of the PPAR receptors, it is notable that also SR13904 (7) [22], reported by Zaveri et al. as well as the acid 3a (8) [23], reported by Kasuga et al., exhibited PPAR $\beta / \delta$ antagonism. In 2010, Shearer et al. reported the potent $\operatorname{PPAR} \beta / \delta$ antagonist GSK3787 (9) [24] which displayed good oral pharmacokinetic properties. This compound was shown to contain a reactive moiety, resulting in the covalent modification of Cys249, a cysteine located centrally in the $\mathrm{PPAR} \beta / \delta$ ligand-binding pocket (LBP). 
<smiles>Cc1cc(SCc2sc(-c3ccc(C(F)(F)F)cc3)nc2C)ccc1OCC(=O)O</smiles>

GW501516 (1)<smiles>O=C(Nc1ccccc1)c1cc([N+](=O)[O-])ccc1Cl</smiles>

GW9662 (3)<smiles>CCCCCCNc1ccc(NS(=O)(=O)c2ccsc2C(=O)OC)c(OC)c1</smiles>

ST247 (5)<smiles>Cc1cc(SCc2sc(-c3cccc4ccccc34)nc2C)ccc1OCC(=O)O</smiles>

SR13904 (7)<smiles>O=C(NCCS(=O)(=O)c1ccc(C(F)(F)F)cn1)c1ccc(Cl)cc1</smiles>

GSK3787 (9)<smiles>CCC(=O)NC[C@H](N/C(C)=C\C(=O)c1ccc(C(F)(F)F)cc1)c1ccc(OCCc2nc(-c3ccccc3)oc2C)cc1</smiles><smiles>COC(=O)c1sccc1S(=O)(=O)Nc1ccc(Nc2ccccc2)cc1OC</smiles>

GSK0660 (4)<smiles>CN1CCN(c2ccc(/C=C(\C#N)c3ccccc3Br)cc2)CC1</smiles>

DG172 (6)<smiles>CCCCOc1ccc(-c2ccc(C(=O)O)cc2)cc1CNC(=O)c1ccc(C(F)(F)F)cc1F</smiles><smiles>Cc1nc(-c2ccc(C(F)(F)F)cc2)sc1C(=O)NCCS(=O)(=O)c1ccc(C(F)(F)F)cn1</smiles>

CC618 (10a)

Figure 1. PPARß/ס modulators. The selective PPAR $\beta / \delta$ agonist GW501516 (1), known PPAR antagonists (2 - 9) and CC618 (10a).

\section{Results and Discussion}

\section{Synthesis of the ligands}

In connection with our interest in developing potent PPAR agonists [25-27] and antagonists [28], we noted that the presence of a thiazole- or an oxazole heterocycle connected to an electron-poor phenyl ring appeared to be beneficial for the binding of agonists, such as GW501516 (1) to the hydrophobic moieties in the LBP of PPAR $\beta / \delta[10,29]$. We envisioned that combining the arylthiazole moiety found in the potent and selective PPAR $\beta / \delta$ agonist GW501516 (1) with the 5-trifluoromethyl-2-pyridylsulfone moiety of GSK3787 (9) would result in antagonism against PPAR $\beta / \delta$ [28].
We thus synthesized CC618 (10a), starting with the condensation of thioamide $\mathbf{1 1}$ and $\alpha$-chloro- $\beta$-ketoester $\mathbf{1 2}$, as previously described [10], followed by basic hydrolysis, to give acid 14. Reacting $\mathbf{1 4}$ with the ammonium trifluoroacetate salt 15a [24] under peptide coupling conditions [30], afforded target compound 10a (Scheme 1). In a similar approach, we prepared an analogue of CC618, $\mathbf{1 0 b}$, lacking the 5-trifluoromethyl group on the pyridine ring.

\section{In vitro evaluations of the ligands}

The antagonistic properties of CC618 (10a) against the three known PPARs were first investigated in luciferase reporter gene assays in Cos-1 cells expressing each of the PPAR subtypes. 
<smiles>NC(=S)c1ccc(C(F)(F)F)cc1</smiles>

11<smiles>CCOC(=O)C(Cl)C(C)=O</smiles><smiles>[R]OC(=O)c1sc(-c2ccc(C(F)(F)F)cc2)nc1C</smiles>

$b\left(\begin{array}{l}13: R=E t \\ 14: R=H\end{array}\right.$

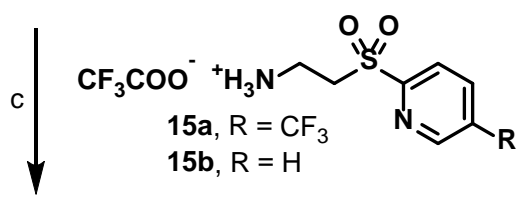<smiles>[R]c1ccc(S(=O)(=O)CCNC(=O)c2sc(-c3ccc(C(F)(F)F)cc3)nc2C)nc1</smiles>

$\operatorname{CC618~(10a):~} \mathrm{R}=\mathrm{CF}_{3}$

10b: $\mathrm{R}=\mathrm{H}$

Scheme 1. Synthesis of the ligands. The synthesis of CC618 (10a) and analog 10b: (a) EtOH, $\Delta$; (b) $\mathrm{NaOH}$ (aq), THF, $\Delta$; (c) 15a or 15b, $\mathrm{Et}_{3} \mathrm{~N}$, DCC, $\mathrm{HOBt}, \mathrm{CH}_{2} \mathrm{Cl}_{2}$.
In the PPAR $\beta / \delta$-expressing cells, CC618 antagonized the effects of $4 \mathrm{nM}$ of GW501516 with an $\mathrm{IC}_{50}=10.0 \mu \mathrm{M}$. In this assay, the previously reported antagonist GSK3787 (9) displayed an $\mathrm{IC}_{50}=5.0 \mu \mathrm{M}$ (Figure 2A). The analog 10b, lacking the 5-trifluoromethyl group, did not display any antagonistic effects (see Supporting Information, Figure S1). On the other hand, neither CC618 (10a) nor GSK3787 (9) displayed any agonistic effects in our assay (Figure 2B). Furthermore, in Cos- 1 cells expressing PPAR $\alpha$, only weak antagonistic effects were observed upon co-treatments of 10a at various concentrations and $200 \mu \mathrm{M}$ of bezafibrate [31]. An even weaker antagonism was observed in Cos-1 cells expressing PPAR $\gamma$, in the presence of various concentrations of 10a and $10 \mu \mathrm{M}$ of rosiglitazone [32]. (see Figures S3 and S4 in the Supporting Information). These results demonstrate that CC618 (10a) is a selective PPAR $\beta / \delta$ antagonist.

\section{CC618 covalently modifies Cys249 in PPAR $\beta / \delta$}

To further investigate the fate of the PPAR $\beta / \delta$ receptor upon treatment with CC618 (10a) or GSK3787 (9), we performed LC-MS/MS analyses of the peptides obtained by reductive alkylation and trypsination of $\operatorname{PPAR} \beta / \delta$, after a $15 \mathrm{~min}$ treatment with $10 \mu \mathrm{M}$ of CC618 (10a) or GSK3787 (9) (see Experimental section for details). In both cases we found that the mass of Cys249 increased by 145 Da, as evidenced by the y-ion series (Figure 3). This mass difference corresponds to the addition of a trifluoromethylpyridyl fragment to the cysteine, with concurrent loss of the thiol proton. These results are in accordance with previous mass spectrometrical observations for GSK3787 [24].
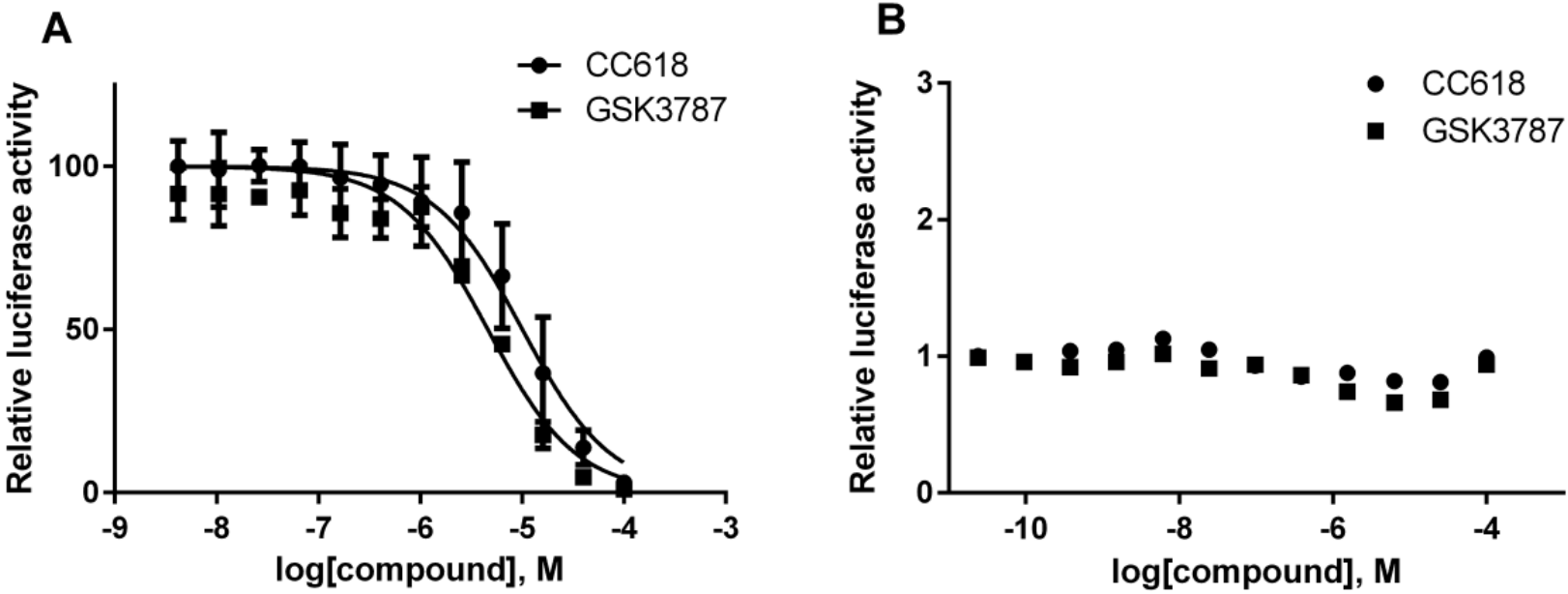

Figure 2. In vitro evaluation of the ligands. Effects of CC618 (10a) and GSK3787 (9) on PPAR $\beta / \delta$ in Cos- 1 cells. A: Antagonist measurements (versus transcription induced with $4 \mathrm{nM}$ GW501516). B: Agonist measurements (10a or 9 alone). The maximum response of the assay was determined as shown in Figure S2 in the Supporting Information. 


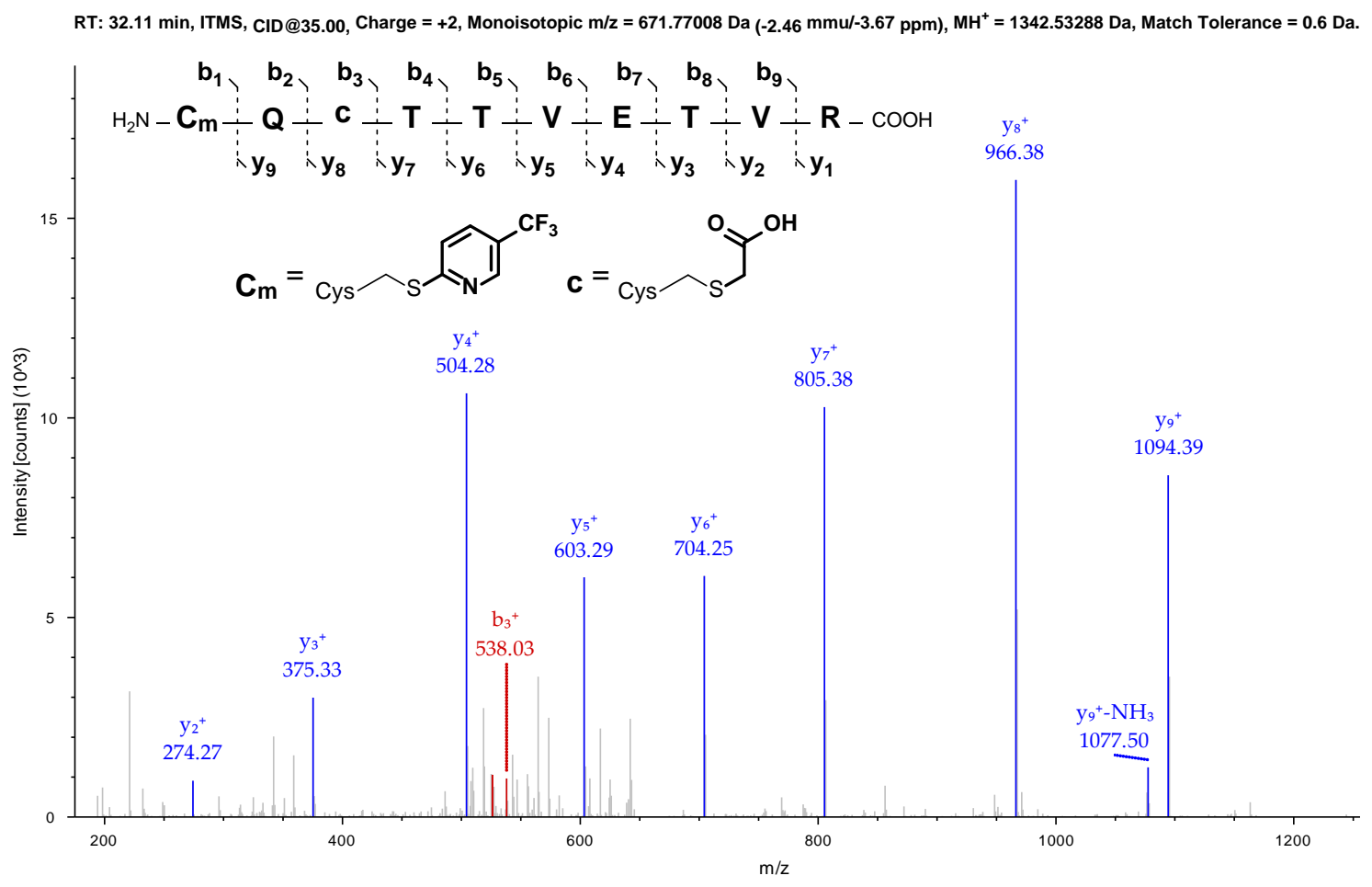

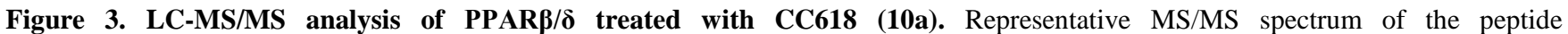
CmQcTTVETVR (residues $249-258, \mathbf{C}_{\mathbf{m}}=$ modified Cys249, $\mathbf{c}=$ carboxymethylated Cys251), obtained from tryptic digestion of human $\mathrm{PPAR} \beta / \delta$ after incubation with $10 \mu \mathrm{M}$ of 10a. Comparison of the mass of the tryptic peptide $\mathrm{MH}^{+}$and ion $\mathrm{y}^{+}$, indicates that Cys249 has an increased mass of 145.13369 Da corresponding, within the match tolerance, to that of the 5-trifluoromethyl-2-pyridyl fragment.

The presence of a reactive cysteine located centrally in the $\mathrm{PPAR} \beta / \delta$ ligand binding pocket is a known trait, conserved throughout the PPARs [33]. The reactivity of the 5trifluoromethyl-2-pyridylsulfone moiety towards a thiol or a thiolate, on the other hand, may be rationalized through a nucleophilic aromatic substitution on an electron-poor 2pyridylsulfone, also called an ipso-substitution. In substitution reactions of alkylsulfonyl aromatics with thiolates or alkoxides, the sulfone moiety acts as the leaving group in the form of an alkylsulfinate (Scheme 2) [34,35].

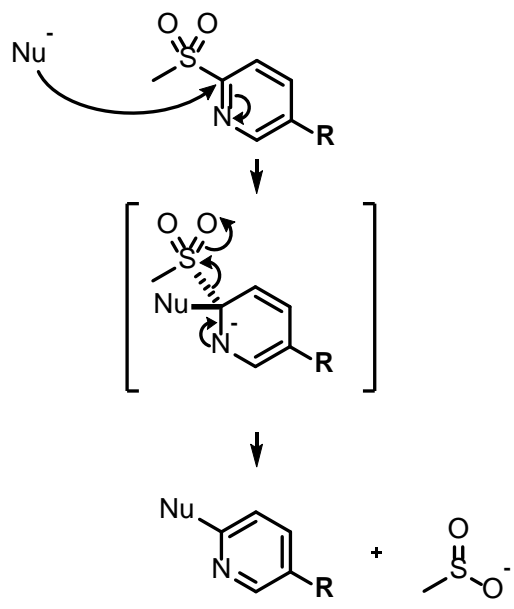

Scheme 2. Mechanistic insight. Schematic representation of a nucleophilic aromatic substitution at the 2-position of a 5-R-2(methylsulfonyl)pyridine, in which $\mathrm{R}=\mathrm{H}, \mathrm{CF}_{3}$.
The reactivity of the compounds $\mathbf{9}$ and 10a towards nucleophiles, compared to simple arylsulfones, should thus be enhanced by the electron-withdrawing natures of both the pyridine nitrogen and the 5-trifluoromethyl group [35]. In a chemical context, a $5-H$ pyridylsulfone is reactive towards alkali metal alkoxide nucleophiles [34], but as compound 10b did not display any antagonistic effects in the reporter assay, the presence of the 5-trifluoromethyl group on the pyridine ring appears to be necessary for the observed reactivity with Cys249. However, the observed effect of the presence of the 5-trifluoromethyl group, in the context of the PPAR $\beta / \delta$ LBP, may be of both a steric and an electronic nature.

\section{Molecular modeling}

In order to visualize and compare the receptor-ligand interactions of CC618 (10a) and GSK3787 (9) prior to an eventual reaction with Cys249, we docked the intact ligands to the PPAR $\beta / \delta$ LBD (PDB: 3GZ9) using Molsoft ICM [36]. As depicted in Figures 4 and 5, CC618 (10a) and GSK3787 (9) are found to bind with similar orientations in relation to the LBP, with C-S distances of $4.3 \AA$ and $3.7 \AA$, respectively, between their $\mathrm{C}-2$ pyridine ring carbons and the sulfur atom of Cys249. The 5-trifluoromethyl-2pyridylsulfone moieties of both compounds occupy the arm of the LBP leading to the residues Tyr473, His413 and His287. Canonically, these residues accommodate the fatty acid carboxylate head group and form a hydrogen bonding network that is thought to be responsible for the stabilization of helix 12, through Tyr473 - a central trait in the pathway of classical agonism in nuclear hormone receptors [37]. The 
perturbation of this stabilization been hypothesized to be a mechanism of nuclear receptor antagonism [38].

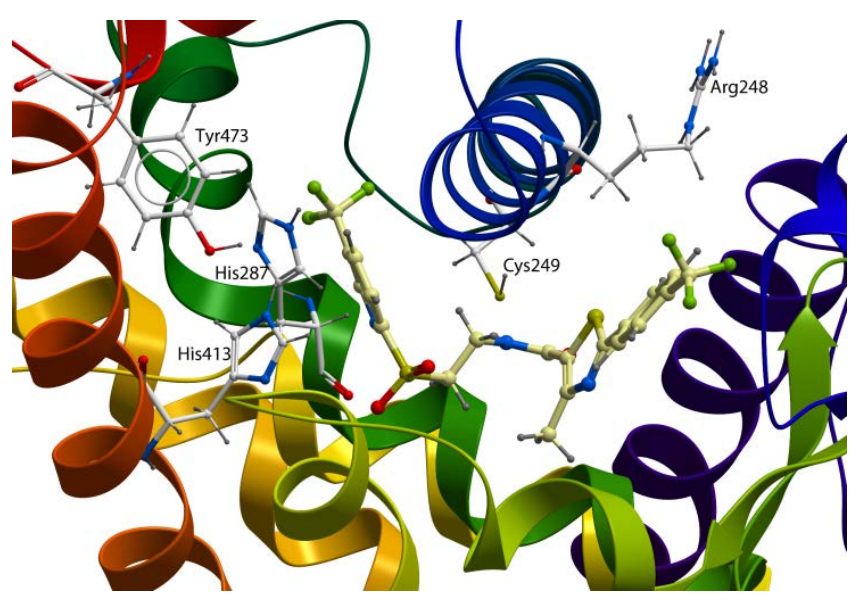

Figure 4. Docking of CC618 (10a). CC618 (10a) docked into PPAR $\beta / \delta$ (PDB: 3GZ9). Color coding of atoms: Red O, blue $\mathrm{N}$, grey H, green F, mustard S and beige C in CC618 (10a); white C in PPAR $\beta / \delta$. The coloring of the ribbons representing the PPAR $\beta / \delta$ backbone is purple, blue, green, yellow, orange and red from $\mathrm{N}$ terminal to C-terminal.

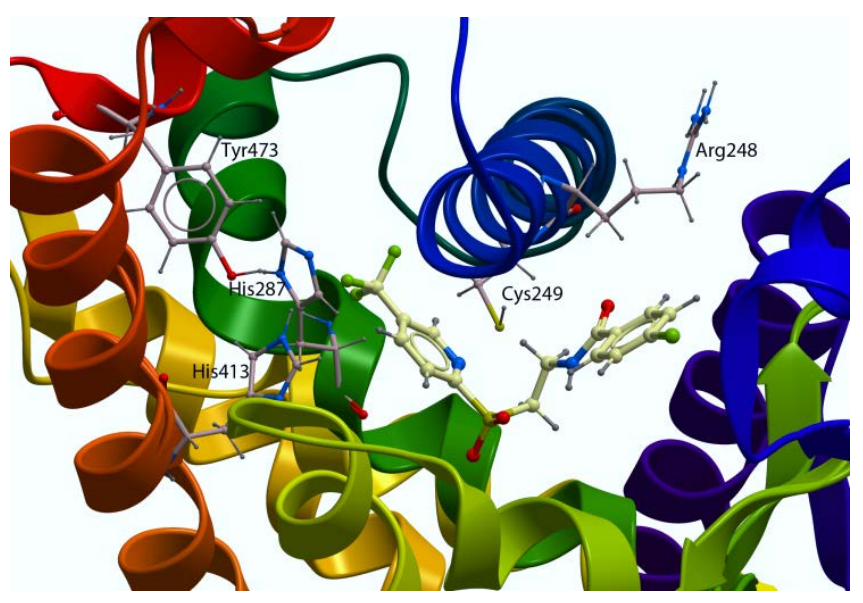

Figure 5. Docking of GSK3787 (9). GSK3787 (9) docked into PPAR $\beta / \delta$ (PDB: 3GZ9). Color coding of atoms: Red O, blue N, grey $\mathrm{H}$, green $\mathrm{F}$, mustard $\mathrm{S}$ and beige C in GSK3787 (9); white/pink C in PPAR $\beta / \delta$. The coloring of the ribbons representing the PPAR $\beta / \delta$ backbone is purple, blue, green, yellow, orange and red from $\mathrm{N}$-terminal to $\mathrm{C}$-terminal.

Currently, there are no single crystal x-ray structures of $\mathrm{PPAR} \beta / \delta$ in complex with an antagonist available in the RCSB Protein Data Bank. Thus, we chose to employ the covalent docking protocol CovDock [39] implemented in the Schrödinger Suite [40] (see Supporting Information for details) in order to visualize possible conformational states of the Cys249 thioether resulting from a reaction with compounds 9 or 10a, assuming that their chemical reactivity (vide supra) is relevant in the context of the protein. The three lowest energy poses of the 5-trifluoromethyl-2-pyridyl thioether (based on their Prime Energy property) are shown in Figure 6. The obtained possible conformations of the 5trifluoromethyl-2-pyridyl thioether in the PPAR $\beta / \delta$ LBP indicate that the covalently attached fragment may perturb Tyr473, His413 or His287 (and thus destabilize helix 12). It is also possible that the 5-trifluoromethyl-2-pyridyl thioether causes receptor inhibition by impeding the access of agonists to the arm of the LBP leading to the mentioned residues.

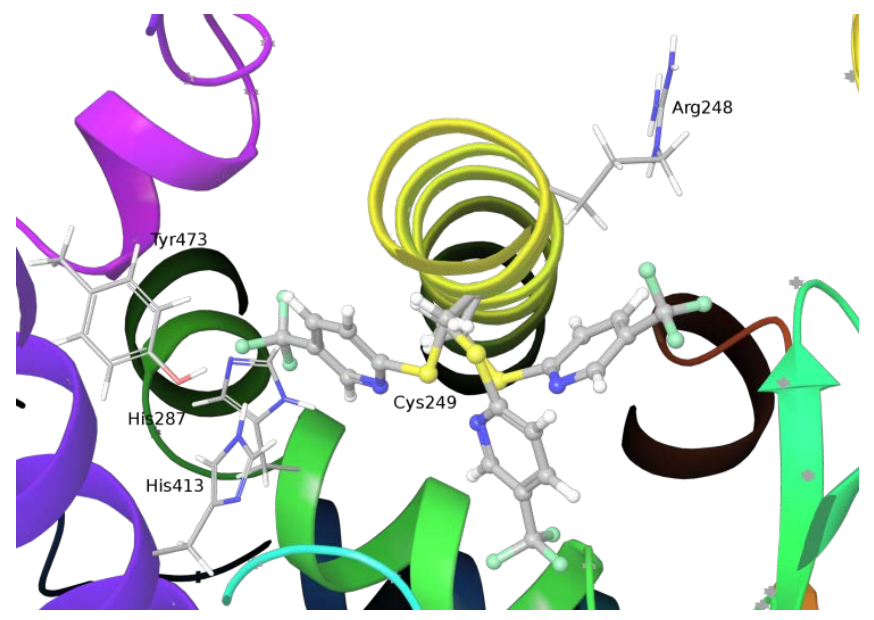

Figure 6. Covalent docking. Three favorable poses (based on their Prime-energy property) of the 5-trifluoromethyl-2-pyridyl thioether resulting from the covalent modification of Cys249 of PPAR $\beta / \delta$ (PDB: 3GZ9), generated with CovDock [39] from the Schrödinger Suite [40]. Color coding of atoms: Red O, blue N, white H, cyan F, yellow $\mathrm{S}$ and grey $\mathrm{C}$. The coloring of the ribbons representing the $\mathrm{PPAR} \beta / \delta$ backbone is brown, orange, yellow, green, blue and purple from $\mathrm{N}$-terminal to C-terminal.

\section{Conclusions}

We have described the synthesis and biological evaluation of the selective PPAR $\beta / \delta$ antagonist CC618 (10a). The inhibitory effect of 10a did not exceed that of GSK3787 (9), but our results render support for the covalent mode of action of the 5-trifluoromethyl-2-pyridylsulfone class of $\mathrm{PPAR} \beta / \delta$ antagonists [24]. Moreover, non-covalent and covalent docking of CC618 (10a) and GSK3787 (9) to the $\mathrm{PPAR} \beta / \delta$ LBP shed light on their similar mode of receptor inhibition.

\section{Experimental Section}

\section{Chemistry}

General information: All commercially available reagents and solvents were used in the form they were supplied without any further purification. The stated yields are based on isolated material. The melting points are uncorrected. Thin layer chromatography was performed on silica gel 60 $\mathrm{F}_{254}$ aluminum-backed plates fabricated by Merck. Flash column chromatography was performed on silica gel 60 (40 - $63 \mu \mathrm{m}$ ) fabricated by Merck. NMR spectra were recorded on a Bruker AVII-400 or a Bruker DPX-300 spectrometer at 400 or $300 \mathrm{MHz}$, respectively, for ${ }^{1} \mathrm{H}$ NMR and at 101 or 75 $\mathrm{MHz}$, respectively, for ${ }^{13} \mathrm{C}$ NMR. Coupling constants $(J)$ are reported in $\mathrm{Hz}$ and chemical shifts are reported in parts per million $(\delta)$ relative to the central residual solvent resonance in ${ }^{1} \mathrm{H}$ NMR $\left(\mathrm{CDCl}_{3}=\delta 7.27\right.$ and DMSO- $\left.d_{6}=\delta 2.50\right)$ and the central carbon solvent resonance in ${ }^{13} \mathrm{C} \mathrm{NMR}\left(\mathrm{CDCl}_{3}=\right.$ $\delta 77.00 \mathrm{ppm}$ and DMSO- $\left.d_{6}=\delta 39.43\right)$. Mass spectra were 
recorded at $70 \mathrm{eV}$ on a Waters Prospec Q spectrometer using EI as the method of ionization. High-resolution mass spectra were recorded on a Waters Prospec Q spectrometer using EI as the method of ionization. Determination of chemical purity of intermediates and final products was performed by HPLC on an Agilent Technologies 1200 Series instrument with a diode array detector set at $254 \mathrm{~nm}$ and equipped with a C18 reverse phase column (Eclipse XDB-C18). The compounds $10 a$ and $\mathbf{1 0 b}$ were $>98 \%$ chemically pure, as judged by HPLC analyses. The TFAsalts 15a and 15b were prepared by deprotection of the corresponding $N$-tert butyl carbamates [24] with TFA in $\mathrm{MeCN}$ and used without further purification. Compounds 13 [30] and 14 [10] are known compounds. GSK3787 (9) [24] and GW501516 (1) [10] were prepared as previously described. Ammonium bicarbonate (ABC), 1,4-dithiothreitol (DTT), iodoacetic acid (IAA) all of analytical grade, formic acid for mass spectrometry (FA, 98\%), and sequencing grade L-1-Tosylamide-2-phenylethyl chloromethyl ketone (TPCK)-treated trypsin from bovine pancreas were purchased from Sigma-Aldrich (St. Louis, MO, USA). Acetonitrile hypergrade for LC-MS (MeCN) and dimethyl sulfoxide (DMSO, dried p.a.) were purchased from Merck, Darmstadt, Germany. MilliQ ${ }^{\mathrm{TM}}\left(\mathrm{mqH}_{2} \mathrm{O}\right)$ water was produced in-house using a MilliQ ${ }^{\mathrm{TM}_{-}}$-system (Merck Millipore, Billerica, MA, USA).

Ethyl 4-methyl-2-4-(trifluoromethyl)phenyl-1,3-thiazole5-carboxylate (13): [30] To a suspension of 4(trifluoromethyl)-thiobenzamide (3.0 g, $14.7 \mathrm{mmol}$.) in EtOH (150 mL) was added, at room temperature, ethyl 2chloroacetoacetate $(2.4 \mathrm{~g}, 2.0 \mathrm{ml}, 14.7 \mathrm{mmol})$. The solution was refluxed for $40 \mathrm{~h}$, and the solvent removed under reduced pressure. The solid material was stirred with cold hexane $(50 \mathrm{~mL})$ for $60 \mathrm{~min}$, filtered, and washed with hexane $(2 \times 25 \mathrm{~mL})$. Drying gave compound 13 (3.5 g, $75 \%$ ) that was sufficiently pure for use in the next step. The spectroscopic data were in accord with those published. ${ }^{1} \mathrm{H}$ NMR (300 MHz, $\left.\mathrm{CDCl}_{3}\right): \delta 8.05(\mathrm{~d}, J=8.1 \mathrm{~Hz}, 2 \mathrm{H}), 7.70$ (d, $J=8.1 \mathrm{~Hz}, 2 \mathrm{H}), 7.35$ (q, $J=7.0 \mathrm{~Hz}, 2 \mathrm{H}), 2.77$ (s, 3H), $1.40(\mathrm{t}, J=7.0 \mathrm{~Hz}, 3 \mathrm{H})$.

4-Methyl-2-4-(trifluoromethyl)phenyl-1,3-thiazole-5carboxylic acid (14): [10] To a cooled solution of 13 (3.5 g, $11.1 \mathrm{mmol})$ in EtOH $(20 \mathrm{~mL})$ was added an aqueous solution of $\mathrm{NaOH}(20 \mathrm{~mL}$ of $6 \mathrm{M}, 120.0 \mathrm{mmol})$ and the mixture was heated at $75-85{ }^{\circ} \mathrm{C}$ for $2 \mathrm{~h}$. After evaporation of the ethanol under reduced pressure, the aqueous solution was diluted with water $(20 \mathrm{~mL})$ and acidified to $\mathrm{pH} 1$ with concentrated aqueous $\mathrm{HCl}$. The precipitated solid material was filtered and washed with water $(2 \times 10 \mathrm{~mL})$ and $\mathrm{CH}_{2} \mathrm{Cl}_{2}$ (10 mL). After drying on a vacuum pump, acid 14 (2.9 g, $92 \%)$ was obtained as a colorless powder that was sufficiently pure for use in the next step. The data was in accord with that published. ${ }^{1} \mathrm{H}$ NMR (300 MHz, DMSO- $\left.d_{6}\right)$ : $\delta 13.20-13.45$ (bs, $1 \mathrm{H}), 8.14$ (d, $J=8.3 \mathrm{~Hz}, 2 \mathrm{H}), 7.84$ (d, $J=$ $8.3 \mathrm{~Hz}, 2 \mathrm{H}), 2.66$ (s, 3H).

\section{4-Methyl-2-(4-(trifluoromethyl)phenyl)- $\mathrm{N}$-(2-(5- (trifluoromethyl)pyridin-2-ylsulfonyl)ethyl)thiazole-5-} carboxamide (10a): To a stirred solution of 2-(5(trifluoromethyl)pyridin-2-ylsulfonyl)ethanamine TFA salt (15a, $115 \mathrm{mg}, 0.4 \mathrm{mmol}$ ) [24] and 4-methyl-2-(4(trifluoromethyl)phenyl)thiazole-5-carboxylic acid (14) (150 $\mathrm{mg}, 0.4 \mathrm{mmol})$ in $\mathrm{CH}_{2} \mathrm{Cl}_{2}(20 \mathrm{~mL})$, triethylamine $(360 \mu \mathrm{L}$,
$2.6 \mathrm{mmol}$ ) was added. To this mixture $N, N^{\prime}$ dicyclohexylcarbodiimide (124 mg, $0.6 \mathrm{mmol}$ ) and 1hydroxybenzotriazole $(81 \mathrm{mg}, 0.6 \mathrm{mmol}$ ) were then added. The reaction mixture was stirred overnight at ambient temperature. The mixture was washed with $\mathrm{H}_{2} \mathrm{O}(3 \times 50 \mathrm{~mL})$ and the remaining organic phase was dried $\left(\mathrm{MgSO}_{4}\right)$ and concentrated. The residue was purified by column chromatography on silica gel with hexane/ethyl acetate (1:1) to obtain the title compound as a colorless solid (147 mg, $72 \%)$. Mp $181-182^{\circ} \mathrm{C}$. The purity (>98\%) was determined by HPLC analysis (Eclipse XDB-C18, $\mathrm{MeOH} / \mathrm{H}_{2} \mathrm{O}, 7: 3,1.0$ $\mathrm{mL} / \mathrm{min}): t_{r}$ (major) $=7.61 \mathrm{~min} .{ }^{1} \mathrm{H}$ NMR $(400 \mathrm{MHz}$ DMSO- $\left.d_{6}\right): \delta=9.18(\mathrm{~s}, 1 \mathrm{H}), 8.56(\mathrm{dd}, J=8.2,1.5 \mathrm{~Hz}, 1 \mathrm{H})$, 8.28-8.20 (m, 2H), 8.10 (d, $J=8.2 \mathrm{~Hz}, 2 \mathrm{H}), 7.87$ (d, $J=8.3$ $\mathrm{Hz}, 2 \mathrm{H}), 3.88$ (t, $J=6.1 \mathrm{~Hz}, 2 \mathrm{H}), 3.68-3.60$ (m, 2H), 2.57 (s, $3 \mathrm{H}) .{ }^{13} \mathrm{C}$ NMR (100 MHz, DMSO-d $\left.)_{6}\right): \delta=164.0,160.5$, 160.0 (q, $J=1.4 \mathrm{~Hz}), 156.1,147.3$ (q, $J=3.5 \mathrm{~Hz}), 137.0$ (q, $J=3.2 \mathrm{~Hz}), 135.8(\mathrm{q}, J=1.2 \mathrm{~Hz}), 130.5(\mathrm{q}, J=32.3 \mathrm{~Hz})$, 128.2 (q, $J=33.1 \mathrm{~Hz}), 126.9,126.3(\mathrm{q}, J=3.9 \mathrm{~Hz}), 126.2$, $124.0(\mathrm{q}, J=272.4 \mathrm{~Hz}), 122.2(\mathrm{q}, J=273.4 \mathrm{~Hz}), 121.3$, 50.3, 33.8, 17.0. HRMS calcd. for $\mathrm{C}_{20} \mathrm{H}_{15} \mathrm{~F}_{6} \mathrm{~N}_{3} \mathrm{O}_{3} \mathrm{~S}_{2}[\mathrm{M}]^{+}$: 523.0459; found: 523.0446.

4-Methyl-2-(4-(trifluoromethyl)phenyl)- $N$-(2-(pyridin-2ylsulfonyl)ethyl)thiazole-5-carboxamide (10b): A solution of tert-butyl (2-(pyridin-2-ylsulfonyl)ethyl)carbamate [24] (214 mg, $0.75 \mathrm{mmol}$ ) in MeCN (3 mL) was cooled on an ice/water bath for a period of 5 minutes, followed by the dropwise addition of trifluoroacetic acid $(3 \mathrm{~mL})$. The solution was stirred for $48 \mathrm{~h}$ at ambient temperature, by which time the starting material had been consumed, as observed by TLC. The volatiles were removed at $60{ }^{\circ} \mathrm{C}$ under reduced pressure, using a water aspirator. Toluene was added to the crude material and the solvent was removed under the same conditions as above. The resulting slightly brown oil and 4-methyl-2-(4(trifluoromethyl)phenyl)thiazole-5-carboxylic acid (14) (216 $\mathrm{mg}, 0.75 \mathrm{mmol})$ were dissolved in $\mathrm{CH}_{2} \mathrm{Cl}_{2}(10 \mathrm{~mL})$ and triethylamine $(0.7 \mathrm{~mL}, 5.03 \mathrm{mmol})$ was added. To this mixture $N, N$-dicyclohexylcarbodiimide (239 mg, 1.16 mmol) and 1-hydroxybenzotriazole (189 mg, $1.12 \mathrm{mmol}$ ) were then added. The reaction mixture was stirred at ambient temperature for $72 \mathrm{~h}$, diluted with $\mathrm{CH}_{2} \mathrm{Cl}_{2}(20 \mathrm{~mL})$, and the organic phase washed with $\mathrm{H}_{2} \mathrm{O}(4 \times 15 \mathrm{~mL})$, dried $\left(\mathrm{MgSO}_{4}\right)$ and concentrated under reduced pressure. The residue was purified by column chromatography on silica gel with heptane/ethyl acetate (1:1) to obtain the title compound as a colorless solid (121 mg, 35\%). The purity (> 98\%) was determined by HPLC analysis (Eclipse XDB$\left.\mathrm{C} 18, \mathrm{MeOH} / \mathrm{H}_{2} \mathrm{O}, 6: 4,1.0 \mathrm{~mL} / \mathrm{min}\right): t_{r}($ major $)=11.88 \mathrm{~min}$. ${ }^{1} \mathrm{H} \mathrm{NMR}\left(400 \mathrm{MHz}, \mathrm{CDCl}_{3}\right) \delta 8.71(\mathrm{~d}, J=4.6 \mathrm{~Hz}, 1 \mathrm{H}), 8.11$ (d, $J=7.8 \mathrm{~Hz}, 1 \mathrm{H}), 8.01$ (d, $J=8.4 \mathrm{~Hz}, 2 \mathrm{H}), 7.98$ (partial t, $J=7.8 \mathrm{~Hz}, 1 \mathrm{H}$ ), 7.67 (d, $J=8.2 \mathrm{~Hz}, 1 \mathrm{H}), 7.56$ (dd, $J=7.7$, $4.8 \mathrm{~Hz}, 1 \mathrm{H}), 7.05$ (bt, $J=5.8 \mathrm{~Hz}, 1 \mathrm{H}), 3.99(\mathrm{q}, J=5.7 \mathrm{~Hz}$, 2H), 3.71 (dd, $J=7.0,4.3 \mathrm{~Hz}, 2 \mathrm{H}), 2.74$ (s, 3H). ${ }^{13} \mathrm{C}$ NMR $\left(101 \mathrm{MHz}, \mathrm{CDCl}_{3}\right) \delta 165.5,161.5,157.0,156.5,150.2$, 138.4, 135.8 (q, $J=1.3 \mathrm{~Hz}), 132.2$ (q, $J=32.8 \mathrm{~Hz}), 127.7$, 126.8 (s, 2C), 126.7, 125.9 (q, $J=3.8 \mathrm{~Hz}, 2 \mathrm{C}), 123.7$ (q, $J=$ $272.4 \mathrm{~Hz}), 122.0,51.8$, 33.8, 17.4. ${ }^{1} \mathrm{H}$ NMR $(400 \mathrm{MHz}$, DMSO- $\left.d_{6}\right) \delta 8.78(\mathrm{~d}, J=4.7 \mathrm{~Hz}, 1 \mathrm{H}), 8.36(\mathrm{bt}, J=5.5 \mathrm{~Hz}$, $1 \mathrm{H}$ ), 8.16 (partial t, $J=7.9 \mathrm{~Hz}, 1 \mathrm{H}$ ), 8.13 (d, $J=7.7 \mathrm{~Hz}$, 2H), 8.08 (d, $J=7.8 \mathrm{~Hz}, 1 \mathrm{H}), 7.88$ (d, $J=8.1 \mathrm{~Hz}, 2 \mathrm{H}), 7.72$ (dd, $J=7.6,4.8 \mathrm{~Hz}, 1 \mathrm{H}), 3.77(\mathrm{t}, J=6.6 \mathrm{~Hz}, 2 \mathrm{H}), 3.61$ (q, $J$ $=6.3 \mathrm{~Hz}, 2 \mathrm{H}), 2.59(\mathrm{~s}, 3 \mathrm{H}) \cdot{ }^{13} \mathrm{C}$ NMR $(101 \mathrm{MHz}, \mathrm{DMSO}-$ $\left.d_{6}\right) \delta 163.9,160.6,156.5,155.6,150.2,139.0,135.7$ (q, $J=$ $1.3 \mathrm{~Hz}$ ), 130.4 (prq, $J=32.0 \mathrm{~Hz}$ ), 128.0, 126.9 (s, 2C), 
126.8, 126.2 (q, $J=3.8 \mathrm{~Hz}, 2 \mathrm{C}$ ), 123.8 (prq, $J=272.4 \mathrm{~Hz}$ ), 121.7, 50.1, 33.6, 16.9. HRMS calcd. for $\mathrm{C}_{19} \mathrm{H}_{16} \mathrm{~F}_{3} \mathrm{~N}_{3} \mathrm{O}_{3} \mathrm{~S}_{2}$ $[\mathrm{M}]^{+}:$455.0585; found: 455.0578 .

\section{In vitro luciferase assays}

Antagonist measurements in luciferase-based transient reporter system: [25,41] Cos- 1 cells (ATCC no. CRL1650) were maintained in DMEM (Invitrogen, Carlsbad, CA) containing gentamicin $(10 \mu \mathrm{g} / \mathrm{mL})$ and fetus bovine serum (10\%), at $37{ }^{\circ} \mathrm{C}$ in a humidified atmosphere of $5 \%$ $\mathrm{CO}_{2}$. Cell confluence never exceeded $80 \%$ before subculturing or transfection. The pSG5-Gal4-hPPAR-LBD $(\alpha, \gamma$ and $\beta / \delta$ subtypes) expression constructs were generous gifts from Dr. Hilde Nebb, University of Oslo, and the pGL35XUAS-SV40 luciferase reporter construct was purchased from Promega Corporation, Madison, WI. Cos-1 cells were transiently transfected with $1.7 \mu \mathrm{g}$ of the expression plasmids and $8.5 \mu \mathrm{g}$ of the reporter construct per $1 \times 10^{7}$ cells. Transient transfection was achieved using the Neon electroporation system (Invitrogen). Cells were seeded ( $2 \mathrm{x}$ $10^{4}$ /well) in 96-plates (white F96 microwell, Nalge Nunc Int., Rochester, NY) and allowed to attach (5 hours) before the test compounds were added. Transfected cells were treated for $19 \mathrm{hr}$ with either CC618 (10a) or 10b in dilution series, as indicated on the $\mathrm{x}$-axis in Figure 2a and in Figure $\mathrm{S} 1$, using vehicle supplemented with $4 \mathrm{nM}$ of the PPAR $\beta / \delta$ agonist GW501516 (1). All values are given relative to the luciferase activity obtained by activating the reporter gene system with 4 nM GW501516 (1). For comparison, the antagonist activity of GSK3787 (9) is demonstrated in the same assay system. All values are relative to the luciferase activity obtained by activating the reporter gene system with $207 \mu \mathrm{M}$ of GW501516 (1), as indicated on the x-axis in Figure S2, The $\mathrm{EC}_{50}$-value of GW501516 (1) was found to be $0.5 \mathrm{nM}$. Luc protein expression was developed (One-Glo Luc assay system, Promega Biosciences, CA USA) and quantified on a luminometer (Envison, PerkinElmer, MA, US). The figures were generated using GraphPad Prism version 6.0, GraphPad Software, La Jolla, California, USA.

\section{Liquid Chromatography - Mass Spectrometry:}

Ligand treatment and in-solution digestion of $\mathrm{N}$-His6PPARß/ס: Human recombinant $N$-His 6 -PPAR $\beta / \delta(10 \mu \mathrm{g}, 1$ $\mathrm{mg} / \mathrm{mL}$, Cayman Chemical), stored at $-80{ }^{\circ} \mathrm{C}\left(\mathrm{CO}_{2}(\mathrm{~s})\right)$, was thawed on an ice/water bath, diluted to a concentration of 50 $\mu \mathrm{g} / \mathrm{mL}$ using $190 \mu \mathrm{L}$ of freshly made $50 \mathrm{mM} \mathrm{ABC}$ buffer, fractionated to 10 stock solutions of $20 \mu \mathrm{L}$ and subsequently refrozen at $-30{ }^{\circ} \mathrm{C}$. Prior to ligand treatment and in-solution digestion, $10 \mu \mathrm{L}$ of the above described $50 \mu \mathrm{g} / \mathrm{mL}$ stock solution of human recombinant $N$-His ${ }_{6}-\mathrm{PPAR} \beta / \delta$ was thawed on ice in a Protein LoBind Eppendorf tube (Eppendorf AG, Hamburg, Germany) and subsequently diluted with $10 \mu \mathrm{L}$ of a freshly made solution of $375 \mu \mathrm{M}$ of DTT in $50 \mathrm{mM}$ ABC buffer. The solution was left on ice for 5 min and then added $10 \mu \mathrm{L}$ of a $30 \mu \mathrm{M}$ solution of compound 9 or 10a in $50 \mathrm{mM}$ ABC buffer (w/0.039\% of MeCN), resulting in a final concentration of $125 \mu \mathrm{M}$ of DTT [42] and $10 \mu \mathrm{M}$ of ligand. The solution was incubated at ambient temperature for $15 \mathrm{~min}$, diluted with $55 \mu \mathrm{L}$ of 50 $\mathrm{mM}$ ABC buffer and added $5 \mu \mathrm{L}$ of a solution containing 50 mM DTT in $50 \mathrm{mM}$ ABC buffer. After incubation for 15 minutes at $95{ }^{\circ} \mathrm{C}$ and subsequent cooling to ambient temperature, $5 \mu \mathrm{L}$ of a freshly prepared solution of $250 \mathrm{mM}$ iodoacetic acid (IAA) in $50 \mathrm{mM}$ ABC buffer was added and the solution was incubated in the dark at ambient temperature for 20 minutes. Following alkylation, $5 \mu \mathrm{L}$ of a freshly prepared solution of containing $2.5 \mu \mathrm{g} / \mathrm{mL}$ bovine trypsin in $50 \mathrm{mM}$ ABC buffer (trypsin:protein ratio, 1:40 $(\mathrm{w} / \mathrm{w})$ ) was added and the sample was incubated at $37^{\circ} \mathrm{C}$ overnight using a Thermomixer Comfort (Thermo Scientific) at $800 \mathrm{rpm}$. The final protein concentration was 5 $\mu \mathrm{g} / \mathrm{mL}$ in all experiments.

LC-MS/MS analysis: Samples of $20 \mu \mathrm{L}$ of the proteolytic peptide mixtures were injected into the Chromeleon Xpresscontrolled Dionex HPLC system (Thermo Scientific, Bremen, Germany) and trapped on a C18, $5 \mathrm{~mm} \times 300 \mu \mathrm{m}$ i.d. Acclaim PepMap $100(5 \mu \mathrm{m})$ enrichment column (Thermo Scientific). The loading mobile phase consisting of $3 \% \mathrm{MeCN}, 0.1 \% \mathrm{FA}$ and $97 \% \mathrm{mqH}_{2} \mathrm{O}$, was delivered at 10 $\mu \mathrm{L} / \mathrm{min}$ for 4 minutes. The analytes were transferred to a $150 \times 0.075 \mathrm{~mm}$ i.d. Acclaim PepMap 100 (pore size $100 \AA$, particle diameter $3 \mu \mathrm{m}$; Thermo Scientific) at $300 \mathrm{~nL} / \mathrm{min}$. The mobile phases consisted of A: $5 \% \mathrm{MeCN}$, 3\% DMSO, $0.1 \% \mathrm{FA}$ and $92 \% \mathrm{mqH}_{2} \mathrm{O}$, and B: $95 \% \mathrm{MeCN}, 3 \% \mathrm{DMSO}$, $0.1 \% \mathrm{FA}$ and $2 \% \mathrm{mqH}_{2} \mathrm{O}$. A linear gradient was run from $0 \%$ to $50 \% \mathrm{~B}$ in 60 minutes. Subsequently, the elution strength was increased to $100 \% \mathrm{~B}$, before the column was regenerated for at least 10 column volumes. Total analysis time per run was 87 minutes. The LC setup was connected to an Xcalibur 2.0.7-controlled LTQ Discovery Orbitrap MS equipped with a Nano-ESI ion source (Thermo Fischer). The nanospray ionization source was operated in the positive ionization mode $(360 \mu \mathrm{m}$ o.d. $\times 20 \mu \mathrm{m}$ i.d. distal coated fused silica emitter, $10 \mu \mathrm{m}$ i.d. tip (New Objective, Woburn, MA, USA)). The spray voltage was set at $2.2 \mathrm{kV}$. The heated capillary was kept at $275^{\circ} \mathrm{C}$. The capillary voltage was set at $45 \mathrm{~V}$ and the tube lens offset at $120 \mathrm{~V}$. The mass spectrometer was operated in data-dependent positive ion mode. Survey MS scans were performed in the orbitrap analyzer at a resolution of 30000 , over a mass range between m/z 250 - $2000 \mathrm{Da}$, with charge state disabled. The up to 6 most intense ions per scan were fragmented by collision induced dissociation (CID) at 35\% relative collision energy, activation time of $30 \mathrm{~ms}$, minimum signal required of 500 and analyzed in the linear ion trap. The wide band activation option was enabled and dynamic exclusion of a time window of 15 seconds was used to minimize the extent of repeat sequencing of the peptides.

Data interpretation: The MS raw files were processed with Proteome Discoverer 1.3 (Thermo Scientific), using the Sequest algorithm, searching against the FASTA file ipi.HUMANpr. May 22, 2014. Enzyme specificity was set to trypsin. The initial parent and fragment ion maximum mass deviations were set to $10 \mathrm{ppm}$ and $0.6 \mathrm{Da}$, respectively. The search included cysteine carboxymethylation and 5- $\mathrm{CF}_{3}-2$-pyridyl modification of cysteine, histidine, arginine or lysine as variable modifications. Peptides had to be fully tryptic, and up to two missed cleavages were allowed. A decoy database search was performed by searching against a database containing the reversed protein sequences with a strict target false discovery rate (FDR) of 0.01 and a relaxed FDR of 0.05 . 


\section{Acknowledgements}

We would like to thank Mr. Jørn E. Tungen, School of Pharmacy, University of Oslo, for technical assistance with the HPLC analyses, and Ms. Siri Hildonen, School of Pharmacy, University of Oslo, for technical assistance with the LC-MS/MS analyses. The School of Pharmacy is acknowledged for a Ph.D.-scholarship to Å.K. Inven2 AS, University of Oslo, the Norwegian Diabetes Foundation, the Anders Jahre's Foundation, The Research Council of Norway (Grant no 174885/130) and UiT The Arctic University of Norway, are all acknowledged for financial support. 


\section{References}

[1] D. J. Mangelsdorf, C. Thummel, M. Beato, P. Herrlich, G. Schutz, K. Umesono, B. Blumberg, P. Kastner, M. Mark, P. Chambon, R. M. Evans, Cell 1995, 83, 835839. DOI: http://dx.doi.org/10.1016/00928674(95)90199-X.

[2] V. Zoete, A. Grosdidier, O. Michielin, Biochim. Biophys. Acta. 2007, 1771, 915-925. DOI: http://dx.doi.org/10.1016/j.bbalip.2007.01.007.

[3] L. Michalik, W. Wahli, Biochim. Biophys. Acta 2007, 1771, 991-998.

DOI: http://dx.doi.org/10.1016/j.bbalip.2007.02.004.

[4] J. M. Peters, F. J. Gonzalez, Biochim. Biophys. Acta 2009, 1796, 230-241. DOI: http://dx.doi.org/10.1016/j.bbcan.2009.06.002.

[5] B. P. Kota, T. H.-W. Huang, B. D. Roufogalis, Pharm. Res. 2005, 51, 85-94. DOI: http://dx.doi.org/10.1016/j.phrs.2004.07.012.

[6] B. Desvergne, L. Michalik, W. Wahli, Physiol. Rev. 2006, 86, 465-514. DOI: 10.1152/physrev.00025.2005.

[7] T. M. Willson, P. J. Brown, D. D. Sternbach, B. R. Henke, J. Med. Chem. 2000, 43, 527-550. DOI: http://dx.doi.org/10.1021/jm990554g.

[8] B. Pourcet, J.-C. Fruchart, B. Staels, C. Glineur, Expert Opin. Emerg. Drugs 2006, 11, 379-401. DOI: http://dx.doi.org/10.1517/14728214.11.3.379.

[9] W. R. Oliver, J. L. Shenk, M. R. Snaith, C. S. Russell, K. D. Plunket, N. L. Bodkin, M. C. Lewis, D. A. Winegar, M. L. Sznaidman, M. H. Lambert, et al., Proc. Nat. Acad. Sci. 2001, 98, 5306-5311. DOI: http://dx.doi.org/10.1073/pnas.091021198.

[10] M. L. Sznaidman, C. D. Haffner, P. R. Maloney, A. Fivush, E. Chao, D. Goreham, M. L. Sierra, C. LeGrumelec, H. E. Xu, V. G. Montana, M. H. Lambert, T. M. Wilson, W. R. Jr. Oliver, D. D. Sternbach, Bioorg. Med. Chem. Lett. 2003, 13, 15171521. DOI: http://dx.doi.org/10.1016/S0960894X(03)00207-5.

[11] H. E. Xu, T. B. Stanley, V. G. Montana, M. H. Lambert, B. G. Shearer, J. E. Cobb, D. D. McKee, C. M. Galardi, K. D. Plunket, R. T. Nolte, D. J. Parks, J. T. Moore, S. A. Kliewer, T. M. Willson, J. B. Stimmel, Nature 2002, 415, 813-817. DOI: 10.1038/415813a.

[12] L. M. Leesnitzer, D. J. Parks, R. K. Bledsoe, J. E. Cobb, J. L. Collins, T. G. Consler, R. G. Davis, E. A. Hull-Ryde, J. M. Lenhard, L. Patel, K. D. Plunket, J. L. Shenk, J. B. Stimmel, C. Therapontos, T. M. Willson, S. G. Blanchard, Biochemistry 2002, 41, 6640-6650. DOI: http://dx.doi.org/10.1021/bi0159581.

[13] G. S. Harmon, M. T. Lam, C. K. Glass, Chem. Rev. 2011, 111, 6321-6340. http://dx.doi.org/10.1021/cr2001355.

[14] K. D. Wagner, N. Wagner, Pharmacol Ther. 2010, 125, 423-435. DOI: http://dx.doi.org/10.1016/j.pharmthera.2009.12.001.

[15] T. Adhikary, K. Kaddatz, F. Finkernagel, A. Schönbauer, W. Meissner, M. Scharfe, M. Jarek, H. Blöcker, S. Müller-Brusselbach, R. Müller, PLoS One 2011, 6, e16344. http://dx.doi.org/10.1371/journal.pone.0016344.

[16] T. Adhikary, D. T. Brandt, K. Kaddatz, J. Stockert, F. Finkernagel, S. Naruhn, W. Meissner, J. Obert, S. Lieber, M. Scharfe, M. Jarek, P. M. Toth, F. Scheer, W. E. Diederich, S. Reinartz, R. Grosse, S. Müller-
Brüsselbach, R. Müller, Oncogene, 2013, 32, 52415252. DOI: http://dx.doi.org/10.1038/onc.2012.549.

[17] A. Ammazzalorso, B. De Filippis, L. Giampietro, R. Amoroso, ChemMedChem 2013, 8, 1609-1616. DOI: http://dx.doi.org/10.1002/cmdc.201300250.

[18] B. G. Shearer, D. J. Steger, J. M. Way, T. B. Stanley, D. C. Lobe, D. A. Grillot, M. A. Iannone, M. A. Lazar, T. M. Willson, A. N. Billin, Mol. Endocrinol. 2008, 22, 523-529. DOI: http://dx.doi.org/10.1210/me.20070190.

[19] S. Naruhn, P. M. Toth, T. Adhikary, K. Kaddatz, V. Pape, S. Dorr, G. Klebe, S. Müller-Brusselbach, W. E. Diederich, R. Müller, Mol. Pharmacol. 2011, 80, 828838. DOI: http://dx.doi.org/10.1124/mol.111.074039.

[20] P. M. Toth, S. Naruhn, V. F. Pape, S. M. Dorr, G. Klebe, R. Muller, W. E. Diederich, ChemMedChem, 2012, 7, 159-170. DOI http://dx.doi.org/10.1002/cmdc.201100408.

[21] S. Lieber, F. Scheer, W. Meissner, S. Naruhn, T. Adhikary, S. Müller-Brusselbach, W. E. Diederich, R. Müller, J. Med. Chem. 2012, 55, 2858-2868. DOI: http://dx.doi.org/10.1021/jm2017122.

[22] N. T. Zaveri, B. G. Sato, F. Jiang, J. Calaoagan, K. R. Laderoute, B. J. Murphy, Cancer Biol. Ther. 2009, 8, 1252-1261.

DOI: http://dx.doi.org/10.4161/cbt.8.13.8691.

[23] J.-i. Kasuga, S. Ishida, D. Yamasaki, M. Makishima, D. Doi, Y. Hashimoto, H. Miyachi, Bioorg. Med. Chem. Lett. 2009, 19, 6595-6599. DOI: http://dx.doi.org/10.1016/j.bmcl.2009.10.021.

[24] B. G. Shearer, R. W. Wiethe, A. Ashe, A. N. Billin, J. M. Way, T. B. Stanley, C. D. Wagner, R. X. Xu, L. M. Leesnitzer, R. V. Merrihew, T. W. Shearer, M. R. Jeune, J. C. Ulrich, T. M. Willson, J. Med. Chem. 2010, 53, 1857-1861. DOI: http://dx.doi.org/10.1021/jm900464j.

[25] C. C. Ciocoiu, N. Nikolić, H. H. Nguyen, G. H. Thoresen, A. J. Aasen, T. V. Hansen, Eur. J. Med. Chem. 2010, 45, 3047-3055. DOI: http://dx.doi.org/10.1016/j.ejmech.2010.03.035.

[26] C. C. Ciocoiu, A. W. Ravna, I. Sylte, T. V. Hansen, Arch. Pharm. Chem. Life Sci. 2010, 343, 612-624. DOI: http://dx.doi.org/10.1002/ardp.201000189.

[27] C. C. Ciocoiu, A. W. Ravna, I. Sylte, A. C. Rustan, T. V. Hansen, Bioorg. Med. Chem. 2011, 19, 6982-6988. DOI: http://dx.doi.org/10.1016/j.bmc.2011.10.020.

[28] C. C. Ciocoiu, Ph. D. Thesis, University of Oslo (NO), 2010. http://urn.nb.no/URN:NBN:no-26907.

[29] H. E. Xu, M. H. Lambert, V. G. Montana, D. J. Parks, S. G. Blanchard, P. J. Brown, D. D. Sternbach, J. M. Lehmann, G. B. Wisely, T. M. Wilson, S. A. Kliewer, M. V. Milburn, Mol. Cell. 1999, 3, 397-403. DOI: http://dx.doi.org/10.1016/S1097-2765(00)80467-0.

[30] M. L. Sierra, V. Beneton, A.-B. Boullay, T. Boyer, A. G. Brewster, F. Donche, M.-C. Forest, M.-H. Fouchet, F. J. Gellibert, D. A. Grillot, M. H. Lambert, A Laroze, C. Le Grumelec, J. M. Linget, V. G. Montana. V.-L. Nguyen, E. Nicodème, V. Patel, A. Penfornis, O. Pineau, D. Pohin, F. Potvain, G. Poulain, C. B. Ruault, M. Saunders, J. Toum, H. E. Xu, R. X. Xu, P. M Pianetti, J. Med. Chem. 2007, 50, 685-695. DOI: http://dx.doi.org/10.1021/jm058056x. 
[31] A. Tenenbaum, M. Motro, E. Fisman, Cardiovasc. Diabetol. 2005, 4, $14 . \quad$ DOI: http://dx.doi.org/10.1186/1475-2840-4-14.

[32] T. M. Willson, J. E. Cobb, D. J. Cowan, R. W. Wiethe, I. D. Corea, S. R. Prakash, K. D. Beck, L. B. Moore, S. A. Kliewer, J. M. Lehman, J. Med. Chem. 1996, 39, 665-668. DOI: http://dx.doi.org/10.1021/jm950395a.

[33] F. Grün in Biochemical and Biological Effects of Organotins, Chapter 3 (Eds.: A. Pagliarani, F. Trombetti and V. Ventrella), Bentham Science, 2012, pp. $\quad 53 \quad-69 . \quad$ DOI: http://dx.doi.org/10.2174/97816080526531120101000i

[34] N. Furukawa, S. Ogawa, T. Kawai, S. Oae, Tetrahedron Lett. 1983, 24, 3243-3246. DOI: http://dx.doi.org/10.1016/S0040-4039(00)88146-0.

[35] S. Oae, N. Furukawa in Advances in Heterocyclic Chemistry, Vol. 48 (Ed.: Alan R. Katritzky), Academic Press Inc., 1990, pp. 1-63. DOI: http://dx.doi.org/10.1016/S0065-2725(08)60337-2.

[36] R. Abagyan, M. Totrov, D. Kuznetsov, J. Comp. Chem. 1994, 15, 488-506. DOI: http://dx.doi.org/10.1002/jcc.540150503.
[37] H. E. Xu, M. H. Lambert, V. G. Montana, K. D. Plunket, L. B. Moore, J. L. Collins, J. A. Oplinger, S. A. Kliewer, R. T. Gampe, D. D. McKee, J. T. Moore, T. M. Willson, Proc. Nat. Acad. Sci. 2001, 98, 1391913924.

DOI: http://dx.doi.org/10.1073/pnas.241410198.

[38] Y. Hashimoto, H. Miyachi, Bioorg. Med. Chem. 2005, 13 , 5080-5093.

DOI: http://dx.doi.org/10.1016/j.bmc.2005.03.027.

[39] K. Zhu, K. W. Borrelli, J. R. Greenwood, T. Day, R. Abel, R. S. Farid, E. Harder, J. Chem. Inf. Model. 2014, 54, 1932-1940. DOI: http://dx.doi.org/10.1021/ci500118s.

[40] Schrödinger Release 2014-2: Maestro, version 9.8, Schrödinger, LLC, New York, NY, 2014.

[41] I. Tzameli, H. Fang, M. Ollero, S. Shi, J. K. Hamm, P. Kievit, A. N. Hollenberg, J. S. Flier, J. Biol. Chem. 2004, 279, 36093-36102. DOI http://dx.doi.org/10.1074/jbc.M405346200.

[42] F. J. Schopfer, M. P. Cole, A. L. Groeger, C.-S. Chen, N. K. H. Khoo, S., R. Woodcock, F. Golin-Bisello, U. N. Motanya, Y. Li, J. Zhang, et al., J. Biol. Chem. 2010, 285, 12321-12333. http://dx.doi.org/10.1074/jbc.M109.091512. 